\title{
P-285 当科における下咽頭扁平上皮がんの臨床検討
}

○得丸貴夫、白倉 聡、畑中章生、岡野 渉、千田邦明、河邊浩明、別府 武 埼玉県立がんセンター＼cjkstart頭頸部外科

下咽頭扁平上皮がんの治療方針は早期がんに対しては放射線治療が主体であり、進行症例に対しては手術治療が主体であ る。現在もその基本方針に変わりはないが、近年はさまざまな治療方法が提案され治療方法の選択肢が多様化している。今 回われわれは、当科において一次治療を行った下咽頭扁平上皮がん症例を対象に臨床検討を行い報告する。対象期間は、 2008年 4 月～2014年12月までとした。対象症例は、194症例で、男性187症例、女性 7 症例。亜部位では、梨状陥凹149症例、 後壁25症例、輪状後部20症例であった。病期別では、stage $1: 21$ 症例、 stage $2: 49$ 症例、 stage $3: 34$ 症例、 stage $4 \mathrm{~A}: 77$ 症例、 stage $4 \mathrm{~B}: 12$ 症例であった。根治治療として手術療法を選択した症例は121症例、放射線療法を選択した症例は73症 例であった。手術療法の中で ESD を行った症例は13症例あり、すべて stage 1 と stage 2 の症例であった。

\section{P-286 下咽頭扁平上皮癌 T3 症例の検討}

○力丸文秀、西 憲祐、佐野仁紀、大森裕文、若崎高裕、藤＼cjkstart賢史、檜垣雄一郎、益田宗幸 九州がんセンター 頭頸科

当科では下咽頭扁平上皮癌症例に対し、T1〜3 症例は㑨頭温存を目的に化学放射線同時併用療法を先行して行っている。 約 40Gy. 時点で効果判定を行い、PR 判定以上の症例は、根治的化学放射線同時併用療法を行い、PR未満であれば咽喉頭摘 出術、頸部郭清術、遊離空腸による再建術を行っている。また㑨頭温存症例の頸部転移陽性例は根治的化学放射線同時併用 療法終了後に施行している。今回われわれはこの治療方針にて加療を行った下咽頭扁平上皮癌 $\mathrm{T} 3$ 症例につきその治療成績 や喉頭温存率を検討した。対象は2000年 1 月〜 2013年 4 月まで当科で上記治療がなされた下咽頭扁平上皮癌症例16例とし た。性別は男性15例、女性 1 例で年齢は45歳から84歳で平均 64.5 歳であった。全16例の粗および死因特異的 3 年 $/ 5$ 年生存

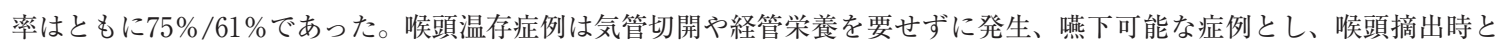
死亡時を起因として算出し、 3 年 $/ 5$ 年喉頭温存率は $31 \% / 25 \%$ であった。

\section{P-287＼cjkstart咽喉頭全摘後の病理検査結果における静脈侵襲の意義}

○齊藤祐䧫、小村 豪、安原一夫、吉田昌史、安藤瑞生、山岨達也

東京大学 医学部 耳鼻咽喉科

【背景】頭頸部癌術後に NCCN は断端陽性、転移リンパ節の節外浸潤を高リスク群として化学放射線療法を、pT3-pT4、 pN2-pN3、静脈侵襲、リンパ管侵襲、神経周囲浸潤を中間リスク群として術後放射線療法を提唱している。当科で施行し た咽喉頭全摘術の予後因子を後ろ向きに検討した。【対象】2004 2014年に施行した咽喉頭全摘術137症例。初回治療として 行った症例が109例、救済治療として行った症例が28例。術後放射線療法は断端陽性、節外浸潤陽性を中心に29例に行った。 【結果】術後 3 年粗生存率、 5 年粗生存率はそれぞれ $48 \%$ 、 $43 \%$ であた。多変量解析では、節外浸潤、放射線療法の既往、 静脈侵襲、梨状陥凹以外の亜部位、転移リンパ節個数が予後不良因子であった。回帰分割分析では、静脈侵襲なし群 (21例 : 3 年粗生存率 $83 \%$ )、静脈侵襲あり - 節外浸潤なし群 (81例：3 年粗生存率 $50 \%$ )、静脈侵襲あり 節外浸潤あり群 $(35$ 例 : 3 年粗生存率18\%）に層別化できた。【結論】咽喉頭全摘術において、静脈侵襲はリスク因子と考えられた。

\section{P-288＼cjkstart初診時に脳転移を認めた頸部食道癌の一例}

○宮崎（次郎丸）梨那、松尾美央子、梅野好啓、小池浩次

$\mathrm{JCHO}$ 九州病院 耳鼻咽喉科・頭頸部外科

頭頸部癌が脳転移を来す場合、多臓器転移後の最終形であることが多い。しかしまれに、脳にのみ単一で遠隔転移を来す 場合がある。今回われわれは、初診時から脳転移のみを有する頸部食道癌の 1 例を経験したのでここに報告する。症例は71 歳男性で、咽頭違和感を主訴に当科を受診。精査の結果、左前頭葉に転移を有する頸部食道癌（扁平上皮癌 cT3N1M1 ＜BRA > ) と診断した。脳転移巣が QOLを最も低下させると判断し、手術にて摘出術を施行。その後原発巣とリンパ節転 移に対し、化学放射線療法を施行した。その後副腎転移など出現したため、化学療法を施行した。今回のように、脳転移は 遠隔転移巣でありながら場合によっては原発制御よりも治療の先行が必要になることがある。今回の症例の経験を交え、脳 転移症例に対する治療について、若干の文献的考察を加え検討しここに報告する。 